\title{
A more quantitative approach to pasture renewal
}

\author{
G.A. KERR ${ }^{1}$, J. BROWN ${ }^{2}$, T. KILDAY ${ }^{3}$ and D. R. STEVENS ${ }^{4}$ \\ ${ }^{\prime}$ Agriseeds, 2547 Old West Coast Rd, RD1, Christchurch 7671 \\ ${ }^{2}$ Camden Group, 309 Ardlui Road, RD13, Rakaia 7783 \\ ${ }^{3}$ Camden Group, 504 Rakaia Terrace Road, RD13, Rakaia 7783 \\ ${ }^{4}$ AgResearch Invermay, Private Bag 50034, Mosgiel 9053 \\ gkerr@agriseeds.co.nz
}

\begin{abstract}
On New Zealand dairy farms the level of pasture renewal has been estimated at $6 \%$ and $8 \%$, with one analysis suggesting greater levels would benefit the economy. There is little research on how farmers set a renewal level, but we suggest five main drivers: crop requirement, historical, an event response, development and cost/benefit driven. This paper presents a case study using a cost/benefit approach to pasture renewal for Willsden dairy farm in Canterbury, which has renewed $28 \%$ and $38 \%$ of the property in the last 2 seasons. On this farm spray-drilling Italian ryegrass has shown an estimated $1.7 \mathrm{t} \mathrm{DM} /$ ha/year extra yield in the season of sowing, with a net value of $\$ 1090 /$ ha, suggesting a payback period of around 5 months and a 198\% return within the season of sowing. This case study shows there is a significant opportunity for dairy farmers to profit from better use of weekly pasture cover information to plan pasture renewal, to better assess the success of any renewal, and for pasture management software developers to provide automated analysis options to support a cost/benefit pasture renewal strategy.
\end{abstract}

Keywords: pasture renewal, spray-drill, spraycultivate, perennial ryegrass, Italian ryegrass

\section{Introduction}

The New Zealand dairy industry's ability to produce quality milk-based products at internationally competitive prices is based on grazing productive pastures in situ (Easton et al. 2002). Unfortunately the performance of pastures often declines over time as weeds replace desirable species (Daly et al. 1999), or the performance of the sown species declines (Parsons et al. 2010). Many factors can cause this, often acting additively, including overgrazing, moisture stress and pest attack (Daly et al. 1999; Bell et al. 2011; Tozer et al. 2011), and this decline is typically not linear but irregular (Stevens 2011).

When the performance of a pasture drops to a certain point a farm may decide to invest in "pasture renewal", removing existing plant species and replacing them with more desirable ones. Pasture renewal can improve both dry matter (DM) yield (for example Thom et al. 1987; Edgecombe 1988; Hamilton-Manns \& Milne 1997; Glassey et al. 2010; Stevens \& Knowles 2011; Tozer et al. 2013), pasture feed value (Glassey et al. 2010; Dalley 2010), and pasture utilisation (Charlton \& Belgrave 1992; Edwards et al. 1993).

The annual rate of pasture renewal on New Zealand dairy farms has been estimated at $6 \%$ of farmed area (Sanderson \& Webster 2009) and more recently at 8\% (Pasture Renewal Charitable Trust 2013), with Sanderson \& Webster (2009) suggesting an increase to $12 \%$ of farmed area would significantly benefit the New Zealand economy, farm gate returns and total gross domestic product (GDP).

Little research has been done on how dairy farmers set a renewal level (Stevens et al. 2007), and levels vary widely between farms (Kelly et al. 2011), but we suggest there are five main drivers:

Crop requirement: Where the farm systems requirement for summer or winter crop is calculated first, with pasture renewal being a by-product of the crop area.

Historical: Where farms undertake a certain amount of the pasture renewal each year, and the budget is set for the season ahead at this historic level. The first and second drivers are often linked.

Event response: This can be at a large or small scale. For example, a significant event such as an extended summer dry period or flood can lead to widespread pasture damage and increased renewal in a region. Or on a small scale, pugging may create a need to renew a paddock.

Development: Areas are often sown as part of farm development, often in tandem addressing factors such as soil fertility and $\mathrm{pH}$, drainage and weeds.

Cost/benefit driven: Analysis of the cost and predicted benefits of pasture renewal lead to a programme to best achieve gains within the constraints of the farm system.

The authors suggest the first four reasons are most common, and few commercial dairy farms currently undertake a cost/benefit approach to pasture renewal. This paper discusses such an approach on Willsden dairy farm in Canterbury, and what might be learnt from this. 


\section{Methods}

\section{Willsden Farm}

Willsden Farm is one of three farms that comprise an 800 ha milking platform owned by the Camden Group at Te Pirita (latitude $43.65^{\circ} \mathrm{S}$; longitude $171.97^{\circ} \mathrm{E}$; altitude $172 \mathrm{~m}$ a.s.1.). Willsden is a 306 ha flat property with Lismore stony silt loam soils (water holding capacity $45 \mathrm{~mm}$ ) converted from dryland sheep grazing in 1994. Farm performance over the last three seasons is outlined in Table 1.

Willsden was initially irrigated with "Rotorainers" until a system upgrade in 2012 to a $700 \mathrm{~m}$ centre pivot covering around $55 \%$ of the property applying up to 10 $\mathrm{mm}$ water every 30 hours. Rotorainers were retained to water the remainder of the farm with an application rate of up to $35 \mathrm{~mm}$ on a 7 day return, based on "Aquaflex" soil moisture monitoring.

Three factors came together to trigger an analysis of the pasture performance on Willsden farm. First, to maintain its milksolids (MS) production the amount of imported feed steadily crept up over 2008-2013, reaching $2.8 \mathrm{t} / \mathrm{ha}$ in 2012/13 (Table 1). Second, the capital spent on more efficient irrigation in 2012 showed little effect on farm performance, indicating other factors were limiting. Finally, in the 2012/13 season several paddocks of new pasture were noted to be growing substantially more than adjacent paddocks, indicating the underperformance of the older pastures. These older pastures contained a significant level of grass weeds, predominantly browntop (Agrostis capillaris), unsurprisingly with the farm's history as a dryland sheep farm less than 20 years before.

\section{Farm DM yield data collection}

The Willsden farm manager undertakes a farm walk to assess pasture cover of individual paddocks across the farm every 10 days through their first grazing round (until around 20 September) and then weekly to the end of the milking season in mid-late May. This walk is regarded by the operations manager as "one of the farm's top five activities in importance". Pasture cover is estimated by eye, which can be relatively accurate where done by experienced operators (Parker 1973). Eye assessments are checked against the Camden Group's operations manager and farm consultant, as well as the continual monitoring of cow grazing and pasture residuals. Data from these farm walks were analysed through LIC's "Land and Feed" software to produce an estimate of yield (t DM/ha/year) for individual paddocks across the farm for each season.

\section{Analysis to determine pasture renew programme}

There are three possible benefits from a renewal programme: extra DM yield, improved pasture feed value and pasture utilisation.

The potential to achieve extra DM yield for individual paddocks through pasture renewal was defined as the difference between the estimated "current growth" and the "potential growth" as demonstrated by Stevens \& Knowles (2011), illustrated for the 2012/13 season in Figure 1. This objective is to identify the paddock(s) with the highest potential for DM gain, which could be realised relatively easily and at a relatively low cost. Possible underlying problems for poor paddock performance were considered (e.g. soil fertility,

Table 1 Summary of Willsden farm production, estimated feed eaten and financial performance for 2012/13, 2013/14 and 2014/15 (estimated) from DairyBase.

\begin{tabular}{|c|c|c|c|}
\hline Factor & 2012/13 & 2013/14 & 2014/15 Est \\
\hline Milking area (ha) & 306 & 306 & 306 \\
\hline Milksolids (kg) & 451656 & 459000 & 470000 \\
\hline Peak cows milked & 1036 & 1036 & 1055 \\
\hline Stocking rate (cows/ha) & 3.4 & 3.4 & 3.4 \\
\hline Nitrogen applied for year (kg N/ha) & 261 & 261 & 261 \\
\hline Milksolids per ha (kg) & 1476 & 1500 & 1536 \\
\hline Milksolids per cow (kg) & 436 & 443 & 445 \\
\hline Pasture eaten (t DM/ha) & 12.3 & 14.2 & 13.5 \\
\hline Imported supplements (t DM/ha) & 2.8 & 1.3 & 2.4 \\
\hline Grazing off dry cows (t DM/ha) & 2.6 & 2.5 & 2.5 \\
\hline Total feed eaten/ha (t DM/ha) & 17.7 & 18.0 & 18.4 \\
\hline Farm working expenses (\$/kg MS) & $\$ 4.15$ & $\$ 4.37$ & $\$ 4.36$ \\
\hline Gross farm revenue (\$/ha) & $\$ 10140$ & $\$ 12595$ & $\$ 9150$ \\
\hline Operating expenses (\$/ha) & $\$ 6555$ & $\$ 7007$ & $\$ 6700$ \\
\hline Operating profit (EFS) (\$/ha) & $\$ 3584$ & $\$ 5588$ & $\$ 2450$ \\
\hline
\end{tabular}




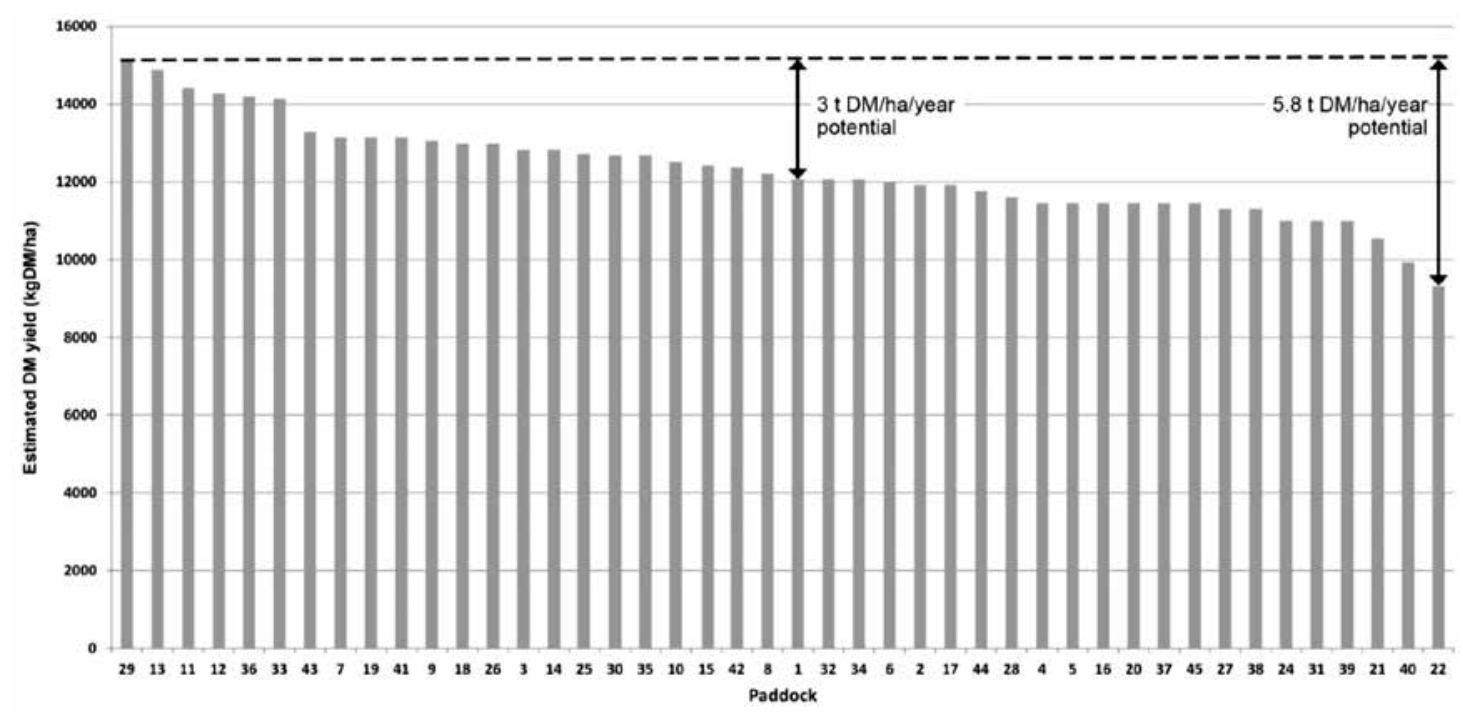

Figure 1 Estimated paddock yield (kg DM/ha) for 2012/13 season for Willsden Farm ranked from highest to lowest, with potential for extra yield (t DM/ha) indicated for paddock 1 and 22.

drainage) and not believed to be an issue.

The maximum yield assessed on Willsden Farm in 2012/13 (Figure 1) was $15.1 \mathrm{t} \mathrm{DM} /$ ha, from paddock 29 , the average $12.0 \mathrm{t} \mathrm{DM} / \mathrm{ha}$ and the minimum $9.3 \mathrm{t}$ $\mathrm{DM} /$ ha. Large variation in paddock performance has been seen in previous studies (Clark et al. 2010), and the data demonstrated there was significant potential for improvement.

\section{Pasture renewal ME and utilisation effects}

The gain in feed quality from new pasture was estimated at an extra $1 \mathrm{MJME} / \mathrm{kg}$ DM for their first season. This assumption was based on the plant species present, as older pastures contained a significant amount of grass weed, published information (e.g. new pastures higher in metabolisable energy (ME) by $0.5-0.9 \mathrm{MJME} / \mathrm{kg}$ DM; Glassey et al. 2010; Dalley 2010), and that spring sown plants do not go to seed for 12 months. A 4\% more efficient conversion of pasture to milksolids was used for the new pasture (DairyNZ 2012).

The gain in utilisation from new pasture was estimated at an extra $10 \%$ eaten of that grown in the first year when plants do not seed. Utilisation is very difficult to measure, but is likely to be better where new pastures have higher ME, and is supported by anecdotal comment - for example the Willsden farm manager commented "In 2013/14 we mowed old pastures on average 2-3 times to maintain quality, but didn't mow any new pastures."

\section{The renewal programme}

An aggressive pasture renewal programme was embarked on in the 2013/14 season, as analysis indicated that there would be significant gains in profitability for this farm. This gave the confidence to renew $28 \%$ of the area of the farm that year, and $38 \%$ in 2014/15 (Table 2).

As browntop was a significant issue the main strategy was a "double spray programme", where glyphosate was sprayed in two successive springs to better control it. In the first spring Italian ryegrass (Lolium multiflorum) cultivar 'Tabu' was spray-drilled (herbicide sprayed then seed direct drilling), and in the following spring perennial ryegrass-based pasture (Lolium perenne) was sown using spray-cultivation (herbicide sprayed, followed by seedbed cultivation, then seed sown) with a mix of cultivars 'Trojan' and 'Bealey' ryegrasses, with 'Kotare' and 'Weka' white clovers.

While the double spray programme was favoured, in 2013/14 there were 33 ha spray-cultivated and sown directly from older pasture in the same perennial ryegrass-based mix to accelerate the renewal process in

Table 2 Pasture species sown on Willsden Farm in 2013/14 and 2014/15, and total percentage of farm area sown.

\begin{tabular}{lccccc}
\hline Year & Italian ryegrass & Perennial ryegrass & Hybrid ryegrass & Total area sown & Total \% farm sown \\
\hline $2013 / 14$ & 39 ha & 33 ha & 13 ha & 85 ha & $28 \%$ \\
$2014 / 15$ & 51 ha & 52 ha & 13 ha & 116 ha & $38 \%$ \\
\hline
\end{tabular}


the first year. In 2014/15 most of the perennial ryegrassbased mix ( 39 ha of the 52 ha) was sown through the double-spray technique.

Sowing was in four separate tranches, each $7-10 \%$ of the farm area. The first two sowings were the Italian ryegrass, around the end of September and October, with the perennial ryegrass-based mixes following in November and December.

While hybrid ryegrass is included in Table 2, to give the total percentage of the farm sown, its analysis is not presented in this paper due to their relatively small area sown.

\section{Reducing risk}

Renewing a large portion of a farm increases the risk of short term feed deficits while paddocks are not available for grazing. To mitigate this, sowings were divided into 4 tranches of a maximum of $10 \%$ of the farm at any one time, the first two sowings were spray-drilled Italian ryegrass to provide a rapid return to grazing, and extra supplement was made available for the spring renewal period.

\section{Renewal costs}

The Camden Group have their own contracting company, run independently, which provides services to Willsden Farm at a commercial rate.

The average cost of spray-drilling Italian ryegrass was \$550/ha. This included spraying glyphosate and chlorpyrifos, $20 \mathrm{~kg} / \mathrm{ha}$ Italian ryegrass seed, directdrilling, slug bait, broadleaf weed spray and a heavy rolling.

Spray-cultivating the perennial ryegrass-clover mix had an average cost of \$750/ha. Extra costs were incurred over spray-drilling Italian ryegrass for the cultivation and more expensive seed, but savings were made with not using chlorpyrifos or slug bait.

Renewal costs often include a value for lost pasture growth during the renewal process. In this analysis the yield data analysed is for the full milking season in which renewal took place, so any lost growth is taken into account.

\section{Statistical analysis}

A regression analysis was undertaken with GenStat Version 17 statistical software by VSN (NZ) Ltd of the estimated yield (t DM/ha) of individual paddocks for the milking season calculated through "Land and Feed" for the 3-year period. The model estimated individual paddock and year effects and removed these from the pasture effects. The effect of pasture renewal was tested for significance $(\alpha=0.05)$ by comparing the "renewed" yields of Italian ryegrass and perennial ryegrassbased pastures against the "unrenewed" paddocks as a baseline.

The statistical analysis was not able to compare the two sowing methods for perennial ryegrass-based pastures, "spray-drilling" versus "following Italian ryegrass", as this was confounded with the year effects, since all the sowings following Italian ryegrass occurred in 2014/15.

\section{Results}

\section{DM yield benefit from Italian ryegrass renewal}

Within the season of sowing, spray-drilling Italian ryegrass gave a significant $(\mathrm{P}<0.001) 1.7 \mathrm{t} \mathrm{DM} /$ ha/year increase in estimated yield averaged across seasons (2.4 t DM/ha in 2013/14 renewal and $1.1 \mathrm{t} \mathrm{DM} / \mathrm{ha}$ in 2014/15 renewal) for the 14 paddocks sown (Table 3 ).

As the measurement period is the milking season, it accounts for any yield loss during renewal. However, it does not account for any extra yield from the Italian ryegrass for the following 6-7 months through winter and spring, until resowing in November/December in the following season. This would likely be an additional $1.5-2 \mathrm{t} \mathrm{DM} /$ ha over unrenewed pasture.

\section{DM yield benefit from perennial ryegrass-based renewal}

The perennial ryegrass based sowings produced a significant $(\mathrm{P}<0.001) 1.9 \mathrm{t} \mathrm{DM} / \mathrm{ha} /$ year increase in estimated yield within the season of sowing, averaged across seasons (Table 3 ).

Although the different sowing methods cannot be statistically analysed, a mathematical average shows that paddocks following Italian ryegrass $(n=6)$ yielded more (1.2 t DM/ha) than paddocks spray-drilled $(\mathrm{n}=6)$.

Table 3 Estimated extra pasture yield (t DM/ha) from new Italian ryegrass and new perennial ryegrass, over unrenewed paddocks, in season of sowing. $n=$ number of paddocks in analysis. Standard error in brackets.

\begin{tabular}{llll}
\hline Italian ryegrass renewal & & Perennial ryegrass-based renewal \\
\hline Yield unrenewed paddocks, $\mathrm{n}=90$ & $12.8(0.14)$ & Yield unrenewed paddocks, $\mathrm{n}=90$ & $12.8(0.14)$ \\
Yield Italian ryegrass paddocks, $\mathrm{n}=14$ & $14.5(0.32)$ & Yield perennial ryegrass paddocks, $\mathrm{n}=21$ & $14.7(0.36)$ \\
Benefit of renewal & $+1.7(0.38)$ & Benefit of renewal & $+1.9(0.44)$ \\
Significance & $\mathrm{P}<0.001$ & Significance & $\mathrm{P}<0.001$ \\
\hline
\end{tabular}


A likely reason for this is these paddocks were in fast growing Italian ryegrass for the first 3-4 months of the season, rather than unrenewed pasture.

\section{Financial return from Italian ryegrass}

It is estimated that the extra DM yield, metabolisable energy (ME) and utilisation of the Italian ryegrass has a revenue value of $\$ 1640 /$ ha using a farm gate price for milksolids (MS) of $\$ 5 / \mathrm{kg}$, less renewal costs of $\$ 550 /$ ha, giving a net benefit of $\$ 1090 /$ ha in the year of sowing (Table 4). This suggests that Italian ryegrass pastures are reaching a financial breakeven in around 5 months, with a $198 \%$ return $(\$ 1090$ benefit on a $\$ 550$ cost) in the season of sowing in this situation.

Financial returns from perennial ryegrass-based pasture are not presented as it is too early to give their full benefit, which will be over a number of years. In their first year their yield advantage was $1.9 \mathrm{t} \mathrm{DM} / \mathrm{ha}$ (Table 3), slightly greater than Italian ryegrass, for a higher \$750/ha renewal cost. The cost benefit and return within the season of sowing will be similar to those for Italian ryegrass.

\section{Discussion}

Many dairy farmers undertake weekly farm walks collecting pasture cover information for tactical management decisions, but it is believed few collate and analyse this for pasture renewal decisions as outlined by Stevens \& Knowles (2011), the Lincoln University Dairy Farm (2012), and in this paper for Willsden Farm.

However, collating the data using current on-farm software is often not easy, and there is an opportunity to provide better tools and information to assist in this.

Paddock yield data were analysed through "Land and Feed" to make the initial pasture renewal decision, and then to monitor the outcomes. This was limited by a range of pre-set options for just the milking season.
For Willsden Farm, for example, it would be useful to analyse the performance of Italian ryegrass paddocks over the 14 months they are used (sown mid spring and sprayed out late spring in the following year). The "Pasture Coach" software has an advantage in this feature, allowing flexible date range periods.

Pasture growth for individual paddocks can also be estimated through the analysis of grazing records, with corrections for supplement made and supplement fed. However, grazing record analysis requires detailed recording, and is complex for farmers to do, particularly for farms with multiple herds such as Willsden. If technology such as electronic-ID with real time GPS tracking becomes available on commercial farms, this could allow practical collation of these data, and a possible alternative analysis.

The approach taken in reporting this on-farm study was to test the results through statistical analysis, which provided a conservative estimate of the net increase in pasture yield. For example for sowing Italian ryegrass this gave a benefit was $1.7 \mathrm{t} \mathrm{DM} / \mathrm{ha}$ compared to a straight mathematical analysis, that a farmer might use, of $2.4 \mathrm{t} \mathrm{DM} / \mathrm{ha}$. The use of either approach provided a positive outcome but the difference between the two does suggest that caution should be taken if potential differences are relatively low. Targeting poor performing pastures, however, remains a cost effective approach.

There is an opportunity for pasture management software developers to provide automated analysis options to support better pasture renewal planning, and better assess the success of any renewal, based on paddock growth across farms. The Irish may be ahead of us in this with "PastureBase Ireland", which is looking to send automated seasonal reports to farmers on paddock performance (French et al. 2014).

With cloud-based data storage there is also the possibility - with the permission of the data owner - of

Table 4 Estimated extra return in season of sowing from spray-drilled Italian ryegrass, over unrenewed pasture.

\begin{tabular}{lccc}
\hline Factor & Unrenewed pasture & Italian ryegrass & Benefit Italian ryegrass \\
\hline Pasture yield (t DM/ha) & 12.8 & 14.5 & 1.7 \\
Assumed ME (MJ ME/kgDM) & 11 & 12 & 1 \\
MJ ME/ha grown & 140800 & 174000 & 33200 \\
Utilisation (\% of grown) & 75 & 85 & 10 \\
ME eaten (MJ ME/ha) & 105600 & 147900 & 42300 \\
Conversion ME to MS (MJ/kgMS) & 145 & 140 & -5 \\
Milksolids (kg MS/ha) & 728 & $\$ 1056$ & 328 \\
Gross value @ \$5/kgMS & $\$ 3640$ & $-\$ 550$ & $\$ 1,640$ \\
Less renewal cost (/ha) & 0 & $\$ 4730$ & $-\$ 550$ \\
\hline Net benefit year of sowing (/ha) & $\$ 3640$ & $\$ 1090$ \\
\hline
\end{tabular}

${ }^{1}$ Paddock yield in season of sowing from Table 3. 
meta-analysis of pasture performance, for example on a within region and between region basis.

\section{Conclusions}

On Willsden farm, the analysis of pasture yield of individual paddocks has given confidence for their investment of over $\$ 130000$ in pasture renewal over the last 2 years.

Analysis of the use of Italian ryegrass has shown it is giving good financial returns within the season of sowing - as well as fulfilling an important role in grass weed control in a double spray programme. Perennial ryegrassbased sowings are showing similar returns to date.

Whether this trend will continue as expected time will tell, but continued on-going cost/benefit analysis will support the strategy for future pasture renewal.

\section{REFERENCES}

Bell, N.L.; Townsend, R.J.; Popay, A.J.; Mercer, C.F.; Jackson, T.A. 2011. Black beetle: lessons from the past and options for the future. Pasture Persistence Symposium. Grassland Research and Practice Series 15: 119-124.

Charlton, J.F.L.; Belgrave, B .R. 1992. The range of pasture species in New Zealand and their use in different environments. Proceedings of the New Zealand Grassland Association 54: 99-104.

Clark, C.E.F.; Romera, A.J.; Macdonald, K.A.; Clark, D.A. 2010. Inter-paddock annual dry matter yield variability for dairy farms in the Waikato region of New Zealand. New Zealand Journal of Agricultural Research 53: 187-191.

DairyNZ. 2012. Facts and figures for New Zealand Dairy Farmers, Version 2: pp. 8

Dalley, D.E. 2010. Regrass your bottom line. Quoted in A. Lee. NZ Dairy Exporter 85(9): 26.

Daly, M.J.; Fraser, T.; Perkins, A.; Moffat, C.M. 1999. Farmer perceptions of reasons for perennial pasture persistence and the relationship of these with management practice, species composition, and soil fertility. Proceedings of the New Zealand Grassland Association 61: 9-15.

Easton, H.S.; Amyes, J.M.; Cameron, N.E.; Green, R.B.; Kerr, G.A.; Norriss M.G.; Stewart, A.V. 2002. Pasture plant breeding in New Zealand: where to from here? Proceedings of the New Zealand Grassland Association 64: 173-179.

Edgecombe, G.A. 1988. The establishment of new pastures on a Waikato dairy farm. Proceedings of the New Zealand Grassland Association 49: 171-176.

Edwards, G.R.; Lucas, R.J.; Johnson, M.R. 1993. Grazing preference for pasture species by sheep is affected by endophyte and nitrogen fertility. Proceedings of the New Zealand Grassland Association 55: 137-141.
French, P.; O'Brien, L.; Shalloo, L. 2014. Precision technology for pasture management. Proceedings of the 5th Australasian Dairy Science Symposium: 326-331.

Glassey, C.B.; Roach, C.G.; Strahan, M.R.; McLean N. 2010. Dry matter yield, pasture quality and profit on two Waikato dairy farms after pasture renewal. Proceedings of the New Zealand Grasslands Association 72: 91-96.

Hamilton-Manns, M.; Milne, G. 1997. Successfully establishing new pastures pp. 129-133. In: Dairy Farming Annual.

Kelly, S.; Smith, E.; Brazendale, R. 2011. Pasture renewal in the Waikato and Bay of Plenty regions: An overview of farmer practice, experience and attitudes. Pasture Persistence Symposium, Grassland Research and Practice Series 15: 21-24.

Lincoln University Dairy Farm. 2012. Identifying poor paddocks - the game breaker! Lincoln University Dairy Farm Focus Day 18 October 2012: 28-31.

Parker, O. F. 1973. Precision feed budgeting in practice. Proceedings of the New Zealand Grassland Association 35 (1): 127-134.

Parsons, A.J.; Edwards, G.R; Newton, P.C.D.; Chapman, D.F.; Caradus, J.R.; Rasmussen, S.; Rowarth, J.S. 2010. Past lessons and future prospects: plant breeding for cool temperate pastures. pp. 272291. In: Proceedings of the 4th Australasian Dairy Science Symposium. Eds. Edwards, G.R.; Bryant, R.H. Christchurch, New Zealand.

Sanderson, K.; Webster, M. 2009. Economic analysis of the value of pasture to the New Zealand economy. Report to the Pasture Renewal Charitable Trust. Business and Economic Research Limited, BERL, Wellington, New Zealand. September 2009.

Pasture Renewal Charitable Trust. 2013. Results from Statistics NZ Agricultural Census for 2011-12. Reported by the Pasture Renewal Charitable Trust. http://www.pasturerenewal.org.nz/article/138.html. Accessed 25 September 2013.

Stevens, D.R.; Walcroft, J.; Casey, M.J.; Burggraaf, V.T.; Fraser, T.J.; Webby, R.; Smeaton, D.; Lambert, M.G. 2007. Literature review on effects of pasture renewal in New Zealand and simulation modelling of those effects on whole farm profitability. AgResearch report prepared for the New Zealand Pasture Renewal Charitable Trust.

Stevens, D.R. 2011. Managing sheep and beef farm systems - where does pasture persistence fit in? Pasture Persistence Symposium. Grassland Research and Practice Series 15: 191-198.

Stevens, D.R.; Knowles, I. 2011. Identifying the need for pasture renewal and valuing the contribution of renewal on a dairy farm - Telford Dairy, a case study. Pasture Persistence Symposium. Grassland Research and Practice Series 15: 211-216. 
Thom, E.R.; Prestidge, R.A.; Barker, G.M. 1987. Tozer, K.N.; Rennie, G.M.; King, W.M.; Mapp, N. Pasture establishment on the dairy farm pp. 50-52. In: Ruakura Farmers' Conference.

R.; Bell, N.L.; Cameron C.A.; Eden, T.M. 2013. Pasture renewal on Bay of Plenty and Waikato

Tozer, K.N.; Cameron, C.A.; Thom, E.R. 2011. Pasture persistence: farmer observations and field measurements. Pasture Persistence Symposium. Grassland Research and Practice Series No.15: 25-30. dairy farms: impacts on pasture production and invertebrate populations post-establishment. Proceedings of the New Zealand Grassland Association 74: 227-234. 
